\title{
The Growth and Efficiency of Galah Shrimp Feed (Macrobrachium Rosenbergii De Man) with the Addition of Caffeine in Commercial Feed
}

\author{
Mahendra ${ }^{1}$, Muhammad Rizal ${ }^{2}$ \\ ${ }^{1}$ Aquaculture study program, Faculty of Fisheries and Marine Sciences, Teuku Umar University, Aceh, \\ Indonesia \\ ${ }^{2}$ Study Program of Fisheries, Faculty of Fisheries and Marine Sciences, Teuku Umar University, Aceh, \\ Indonesia \\ mahendra@utu.ac.id
}

\begin{abstract}
Galah shrimp (Macrobrachium rosenbergii de Man) was a high economic level fishery commodities. The efforts to increase productivity in galah shrimp cultivation can be done by applying efficiency the use of feed. One ingredient to reduce the large feed costs in feed production was from the type of caffeine compound. This study was aimed to analyze the dose of caffeine addition in the best feed on the growth and efficiency of shrimp feed. The method used was a completely randomized design experiment with 5 treatments and 3 replications. Caffeine levels used were 0; 0.5; 1; 1, 5; and 2 gr per $\mathrm{kg}$ of feed. The parameters observed were growth and feed efficiency. The results showed that the best addition of caffeine was $P 5=2 \mathrm{gr} / \mathrm{kg}$ of feed producing a specific growth rate of $0.0065 ;$ FCR 0.15 and EP 6.8 . From the results of this study that the addition of caffeine in feed can have a positive effect on the observed parameters $(P<0.05)$.
\end{abstract}

Keywords: Galah shrimps; growth; feed efficiency; caffeine.

\section{Introduction}

Galah shrimp (Macrobrachium rosenbergii de Man) is a high economic level fishery commodities with a selling price of up to Rp. 185,000 / kg (Coal and Gustianty, 2016). The high selling price has an impact on the high demand for galah shrimp seeds. Cultivation of galah shrimp is currently experiencing quite rapid development. However, in various field conditions many problems arise due to the lack of socialization in the culture system and the lack of mastery of specific technologies in galah shrimp cultivation.

The efforts to increase productivity in the aquaculture business of galah shrimp can be done by applying efficient use of feed because the feed absorbs $60 \%-70 \%$ of the total cost of shrimp production. Nutrient requirements especially protein, fat and fiber are different according to species, age, physiological condition and environment. Foods that have a balance of protein, fat and fiber will produce a good growth of shrimp growing, but if the lack of nutrition due to low feed quality will result in stunted shrimp growth resulting in increased production costs due to long maintenance time. Besides being determined by the quality of feed, shrimp growth is also very much determined by the digestibility of the feed it consumes.

One ingredient to reduce the large feed costs in feed production is from the type of caffeine compound. Caffeine is a natural alkaloid or xanthine alkaloid found in coffee beans, tea leaves, cocoa beans, nuts and other plants (Nonthakaew, 2015). The use of caffeine in the aquaculture world has been carried out on freshwater fish (carp, catfish and tilapia) and sea fish (Sparus aurata). According to Chatzifotis et al., (2009) the use of caffeine in feed on Sparus aurata can reduce the FCR value of 1.8 at a dose of 1 gram of caffeine in $1 \mathrm{~kg}$ of feed. Therefore, research on the role of caffeine compounds in galah shrimp feed can emphasize the efficiency of the feed so that the cost of feed production can be reduced. 
Feed has an important role in increasing the production of cultivation activities. The feed given must be of high quality, nutritious and meet the requirements for shrimp consumption, and be available continuously so that it does not interfere with the production process and can provide optimal growth. The formulation of the problem that needs to be done in this study is to determine the growth and efficiency of galah shrimp feed by adding caffeine in commercial feed.

\section{Research Methods}

\subsection{Research Location}

This research was conducted in Hachery, Seuneubok Village, Johan Pahlawan Subdistrict, and West Aceh District from preparation to data collection.

\subsection{Materials and Instruments}

The materials used in this study were: 1) galah shrimp seeds (0.01 - 0.02 gr) 2) pellets (gold coin size F0), 3) caffeine (Caffeine anhydrous), 4) Shelter (coconut leaves), 5) black plastic, and 8) chlorine.

The instruments used in this study were: 1) 18 liter aquarium, 2) DO meter, 3) pH meter, 4) thermometer, 5) blower, 6) scales, 7) calipers, 8) seser, and 9) measuring cup

\subsection{Trial Design}

The method used in this study was an experimental method and the design used was a Completely Randomized Design (CRD) consisting of 5 treatments with 3 replications each. The treatment of each material used in this study includes:

$\mathrm{P} 1=$ caffeine dose of $0 \mathrm{gr}$ in $1 \mathrm{~kg}$ of feed

$\mathrm{P} 2=$ caffeine dose of $0.5 \mathrm{gr}$ in $1 \mathrm{~kg}$ of feed

$\mathrm{P} 3=$ caffeine dose of 1 gram in $1 \mathrm{~kg}$ of feed

$\mathrm{P} 4=$ caffeine dose of 1.5 gram in $1 \mathrm{~kg}$ of feed

$\mathrm{P} 5$ = caffeine dose of 2 grams in $1 \mathrm{~kg}$ of feed

\subsection{Research Procedures}

The container used is the aquarium which is disarmed first by washing the aquarium thoroughly using chlorine and then rinsed and filled with as much as 15 liters of water. Experimental material was the addition of caffeine in commercial feed, the dose of caffeine adjusted to each treatment in $1 \mathrm{~kg}$ of feed. Galah shrimp that have been adapted simultaneously are put into each experiment container according to the treatment with a density of 60 individuals per experiment container (Abidin, 2011). Each container is covered with black plastic which aims to condition it according to the nature of nocturnal galah shrimp (nocturnal) so that stimulated prawns can eat during the day. Each container is equipped with a shelter made from coconut branches placed inside the container. Before inclusion, the measurement of galah shrimp biomass is measured. Maintenance lasts for 10 days and feed is given with a frequency of 3 times a day that are in the morning, afternoon and evening. Data obtained from measurements at the beginning and end of the experiment. Measuring temperature, $\mathrm{pH}$, and dissolved oxygen which is a parameter of water quality that is feasible for the maintenance of galah shrimps. Maintenance of galah shrimp seeds includes rule (penyiponan), water change, water quality checking, health checking, and shrimp death. Feeding rate is $3 \%$ of biomass. 
Penyiponan (rule) is done before the water change and is done twice during the study before giving shrimp feed in the morning.

\subsection{Research Parameters}

Specific Growth Rate (SGR)

Growth rates can be calculated using the formula by Rahman et al., (2019) is as follows:

Information:

$$
S G R=\frac{L N W_{t}-L N W_{0}}{t} \times 100 \%
$$

SGR : Specific Growth Rate (\%)

W0 : Initial weight of galah shrimp (g)

Wt : Final Weight of galah shrimp (g)

t : Time (day)

\section{a. Feed Conversion Rate (FCR)}

Feed conversion can be calculated with the formula by Rahman et al., (2019) is as follows:

Information:

$$
F C R=\frac{F}{(W t+D)-W 0}
$$

FCR : Feed conversion ratio

F : Weight of the given feed (gr)

Wt : Animal biomass test at the end of maintenance (gr)

D : Weight of dead prawns (gr)

Wo : Animal biomass test at the beginning of maintenance (gr)

\section{b. Feed Efficiency (EP)}

Efficiency of feed utilization is calculated by the formula by Suwannasang et al., (2017) is as follows:

Information:

$$
E P=\frac{(W t+D)-W 0}{F}
$$

EP : Feed utilization efficiency (\%)

Wt : Weight at end of period of prawn rearing (gr)

Wo : Weight at the beginning of the period of maintenance of galah shrimp (gr)

$\mathrm{F} \quad$ : Weight of the given feed (gr)

c. Water Quality Analysis

Water quality measurements include temperature, $\mathrm{DO}$, and $\mathrm{pH}$. Time of measurement in the morning and evening every week. The instrument and methods for water quality parameters can be seen in table 1. Below:

Table 1. Instruments and methods for measuring the quality of galah shrimp water quality parameters

\begin{tabular}{lllll}
\hline No & Variable & Tool & Method & References \\
\hline 1 & Temperature & Thermometer & Insitu & Taqwa (2008) \\
2 & Dissolved oxygen & Do-meter & Insitu & Taqwa (2008)
\end{tabular}




$3 \mathrm{pH} \quad \mathrm{pH}-\mathrm{meter} \quad$ Insitu Taqwa et al., (2008)

\section{Data analysis}

The data obtained will be grouped, tabulated, statistical tests of ANOVA and SPSS are done to see the effect of the experiment. If there are significant differences, Tukey will continue testing.

\section{Results and Discussion}

\subsection{Specific Growth Rate}

The results of specific growth rates of galah shrimp for each treatment and repetition during the 10-day maintenance period are presented in Figure 1.

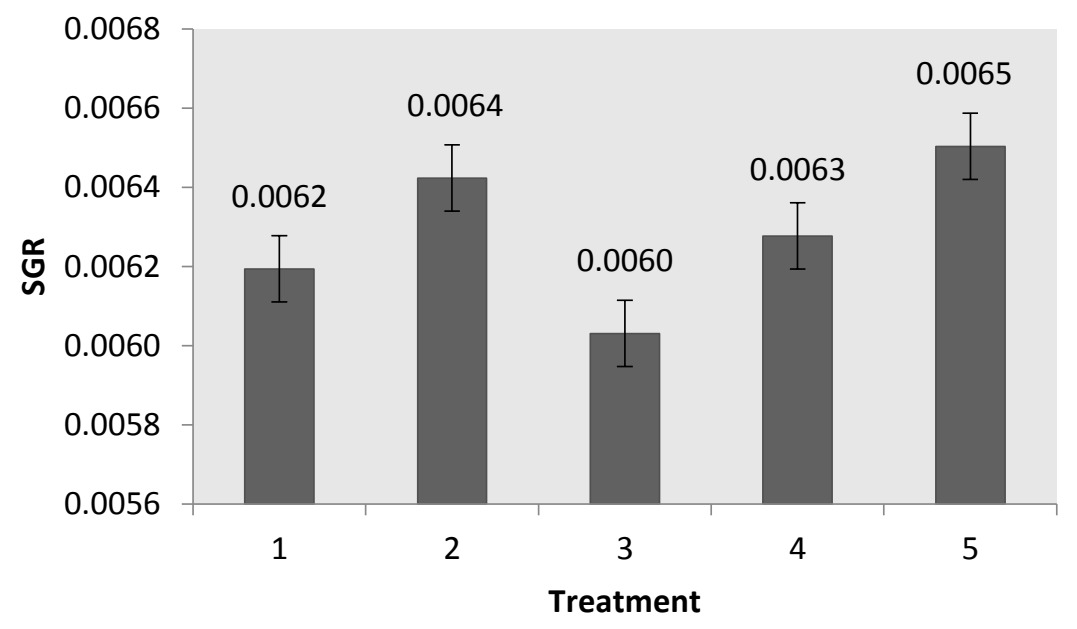

Figure 1. Specific growth rate of galah shrimps

Growth is a combination of behavioral and physiological processes. The physiological process is the process of utilizing the food consumed, while behavior is a way of consuming feed. The amount of food consumed by galah shrimp is affected by species, age, size, food availability, nutritional value, and environmental conditions (Kadarini, 2009).

The results of the study based on Figure 1 note that the lowest specific growth rate value in this study was the P3 treatment with a value of 0.0060 . Whereas the highest specific growth rate was found in treatment P5 with 0.0065 . The results of this study indicate that the addition of caffeine P5: $2 \mathrm{gr} / \mathrm{kg}$ of feed plays a role in supporting the growth of galah shrimps.

Some aspects of physiological processes related to individual growth include regeneration, metamorphosis and moulting. Moulting is the periodic removal process of old shells and the formation of new shells of larger sizes. In crustaceans, growth occurs periodically after skin replacement. Increased body weight will be hampered if not preceded by the process of skin replacement (Affandi and Tang, 2002).

A high growth rate is characterized by a faster skin dressing process. The process of caffeine transfer from hemolymph to shrimp shells requires a large amount of energy. This large energy requirement is obtained from the feed consumed. Feeding is an energy requirement to support a faster growth rate. This is closely related to growth where when consumption of feed is high, there is a lot of energy available that can be used for various 
purposes of life and by reducing energy expenditure, so that the portion of energy available for growth is greater. If the physiology of the shrimp goes well, including metabolism, then the utilization of feed is more efficient and ultimately growth can increase (Zaidy, 2007). The results of the analysis of variance showed that the treatment of P5, that is the addition of caffeinated feed ( $2 \mathrm{gr} / \mathrm{kg}$ of feed) significantly affected the specific growth rate.

\subsection{Feed Conversion Ratio and Feed Efficiency}

The results obtained from the study of the calculation of shrimp feed conversion parameters and efficiency of galah shrimp feed during 10 days maintenance can be seen in Figures 2 and 3 below.

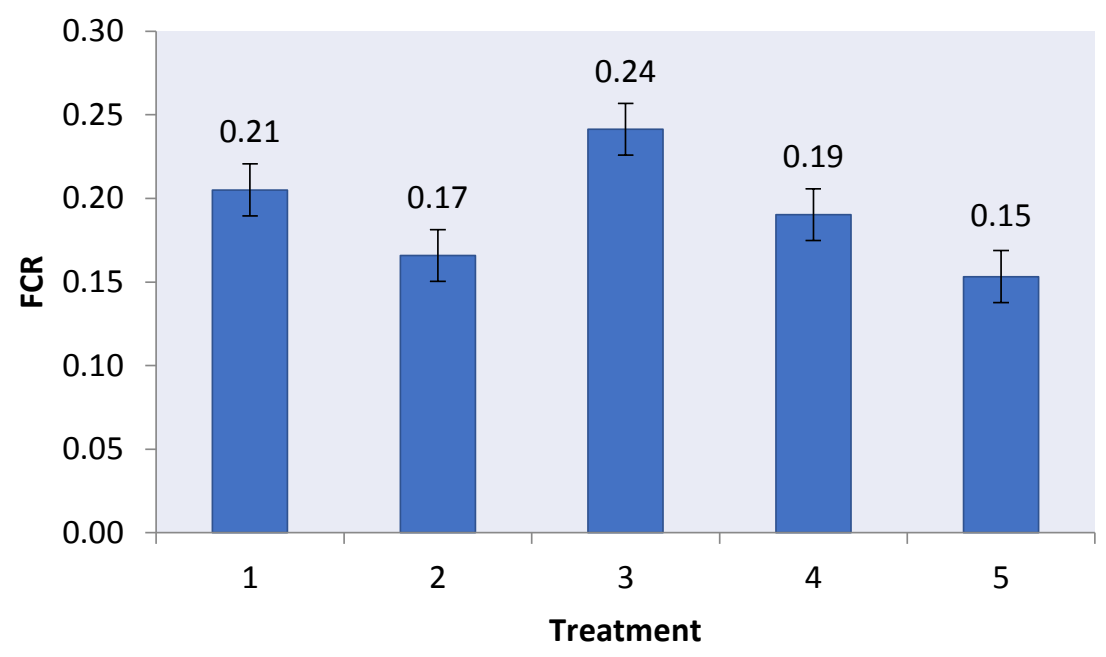

Figure 2. Pellet Shrimp Feed Conversion Ratio

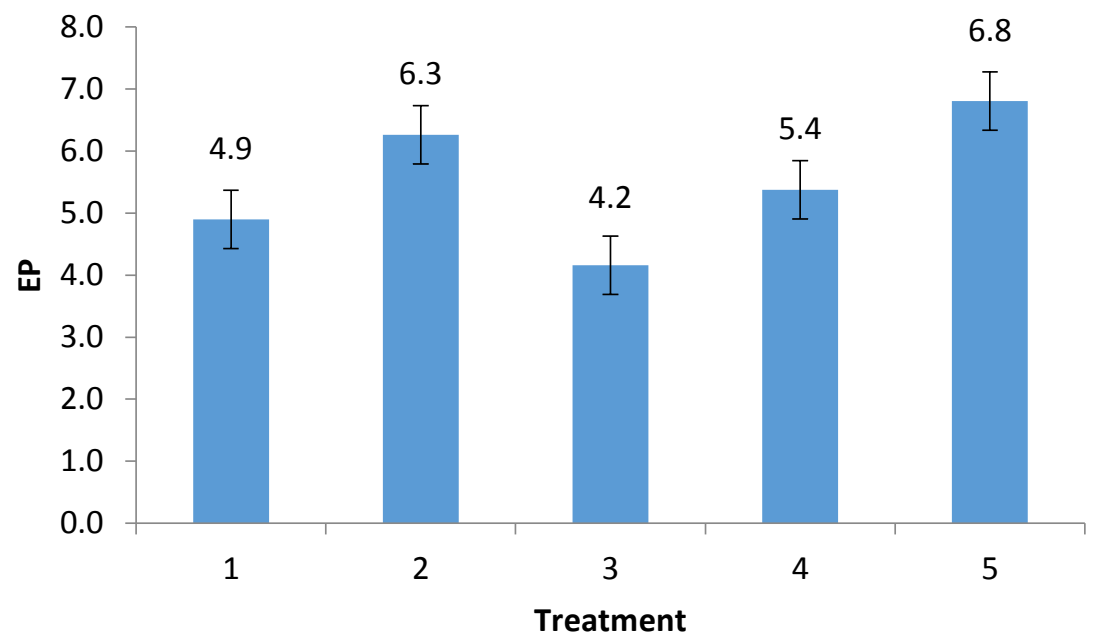

Figure 3. Efficiency of Galah Shrimp Feed

FCR values indicate the utilization of feed nutrients by shrimp, the lower FCR values produced indicate the use of the feed is more efficient (Radona et al., 2017). The results of the study based on Figure 2 note that the highest feed conversion value in this study was P3 
treatment with a feed conversion value of 0.24 . While the lowest feed conversion value is in treatment P5 with feed conversion value of 0.15 .

Feed conversion is a comparison between the amounts of feed given to the total weight of shrimp produced. The smaller the value of feed conversion means the level of efficiency in the use of feed is better, conversely if the conversion of feed is large, the level of efficiency of feed utilization is not good. Thus, feed conversion illustrates the level of efficiency in which feed utilization is achieved. The average yield of feed conversion at each treatment during maintenance can be seen in Figure 2.

Feed conversion value shows how much feed is consumed into shrimp body biomass. The analysis showed that the lowest feed conversion value during maintenance was in treatment $5(0.15)$, followed by treatment $2(0.17)$, treatment $4(0.19)$ treatment $1(0.21)$ and treatment $3(0.24)$ thus the caffeinated commercial feed provided has good quality, because the feed given can actually be utilized by shrimp for maximum growth. P5 treatment has a better feed efficiency level because it has a lower feed conversion value. As the statement of Fran et al., (2011), that the value of feed conversion is used to determine the quality of the feed provided for the growth of biota. The low feed conversion means the higher the efficiency of the feed and conversely the higher the value of feed conversion, the lower the efficiency.

Iskandar and Elrifadah (2015) stated that the value of the feed conversion ratio is influenced by feed protein, feed protein that is in accordance with the nutritional needs of biota resulting in more efficient feeding. Besides it is influenced by the amount of feed given, with the less amount of feed given, the more efficient feed.

Feed efficiency is the proportion of biota biomass accretion with the amount of feed consumed by biota (Giri et al., 2007). Whether or not a good feed quality is not only seen from the value of feed conversion, but can also be shown from the value of feed efficiency. The determinants of high and low feed efficiency are the type of nutrient source and the amount of each component of the nutrient source in the feed (Hariyadi et al., 2005). The value of feed efficiency is obtained from the comparison between the body weight gain of biota and the amount of feed consumed by shrimp during the maintenance period. The greater the value of feed efficiency, means the more efficient the shrimp use the food consumed for growth. Besides it is influenced by the amount of feed given, with the less amount of feed given, the more efficient feed.

Higher feed efficiency in the P5 treatment is influenced by the high dose of caffeine compared to other treatments. Fran et al. (2011), states that the level of protein energy contained in biota feed influences the level of efficiency and effectiveness in the use of feed. Feed conversion and efficiency are closely related to digestibility. The greater the digestibility value of a feed, the more nutrients in the feed are used for biota growth (Hanief and Subandiyono 2014).

\subsection{Water Chemistry Physics Parameters}

The measurement data of water chemical physics parameters during the research can be seen in table 2 . The value of water chemical physics parameters during the study in general is still good to support the growth of galah shrimps.

Table 2. Value of chemical physics parameters of galah shrimp water

\begin{tabular}{ccccc}
\hline Treatment & Caffeine Dosage $(\mathrm{gr})$ & Temperature $\left({ }^{\mathbf{0}} \mathbf{C}\right)$ & $\mathbf{p H}$ & DO $(\mathbf{p p m})$ \\
\hline P1 & 0 & $28-29$ & $7-9$ & $5,0-5,9$ \\
P2 & 0,5 & $28-29$ & $7-9$ & $5,0-5,7$
\end{tabular}




\begin{tabular}{ccccc} 
P3 & 1 & $28-29$ & $7-9$ & $4,8-5,9$ \\
P4 & 1,5 & $28-29$ & $7-9$ & $5,3-5,4$ \\
P5 & 2 & $28-29$ & $7-9$ & $4,9-5,8$ \\
\hline
\end{tabular}

The temperature range on the galah shrimp rearing media during the study was $27-29^{\circ} \mathrm{C}$. Temperature affects the physical and chemical processes of the waters. An increase in temperature results in an increase in chemical reactions. Galah shrimp can grow well in the temperature range of 27-300C (Mahendra, 2015). Drastic changes in temperature will result in the death of juvenile shrimp and high temperatures tend to result in decreased dissolved oxygen levels

The range of $\mathrm{pH}$ values during the study was 7-9. This range is still good to support the growth of galah shrimps. The $\mathrm{pH}$ value characterizes the balance between acids and bases in water and is a measurement of the activity of hydrogen ions in solution which directly affects the growth rate and graduation of galah shrimps. A good $\mathrm{pH}$ range for raising galah shrimp is 7 - 9.5 (Mahendra, 2015).

Dissolved oxygen level is a limiting factor in aquaculture. Good dissolved oxygen levels with levels $>4$ ppm can support shrimp life. Low levels of dissolved oxygen in water can cause aquatic organisms to become stressed. Aquatic organisms use energy to survive stress conditions, so energy for growth is reduced. Stress increases rapidly when the organism's endurance limit is exceeded. The impact of this stress results in decreased body endurance and results in death (Zonneveld et al., 1991).

The management of water chemistry physics during research is an appropriate step to maintain the viability of the media water conditions. You do this by removing the remaining food and shrimp manure that has accumulated at the bottom by padding twice for 10 days and also by applying biosecurity at the research site by covering it with black plastic, so that the temperature condition is always maintained. Based on data from the measurement of the chemical physical properties of water that the physical parameters of chemical media are still at a decent condition to support the survival and growth of galah shrimps.

\section{Conclusion}

The addition of caffeine in commercial feed has an effect on the growth and efficiency of galah shrimp feed from the best dose of caffeine in the treatment of P5 $=2 \mathrm{gr} / \mathrm{kg}$ of feed producing a specific growth rate of 0.0065 ; FCR 0.15 and EP 6.8 .

\section{Acknowledgments}

The author's research was funded by an internal research grant from Teuku Umar University especially the LPPM and Quality Assurance and the Aquaculture Study Program of the Faculty of Fisheries and Marine Sciences.

\section{References}

Abidin, J. (2011). Penambahan Kalsium untuk Meningkatkan Kelulusan Hidup dan Pertumbuhan Juvenil Udang Galah (Macrobrachium rosenbergii de Man) Pada Media Bersalinitas. Bogor: Institut Pertanian Bogor. 
Affandi, R. and Tang, U., M. (2002). Fisiologi Hewan Air. Universitas Riau, Riau.

Batubara and Gustianty. (2016). Laju Pertumbuhan Dan Kelangsungan Hidup Udang Galah (Macrobranchium rosenbergii de Man) Skala Laboratorium. Kisaran: Universitas Asahan.

Chatzifotis, S., Kokou, F., Ampatzis, K., Papadakis, I.E., Divanach, P and Dermon, C.R. (2009). Eff ects Of Dietary Caff eine On Growth, Body Composition, Somatic Indexes, And Cerebral Distribution Of Acetyl-Cholinesterase And Nitric Oxide Synthase In Gilthead Sea Bream (Sparus aurata), Reared In Winter Temperature. Aquaculture Nutrition. 14(5): 405-415

Fran, S., Arifin, S. and Akbar, J. (2011). Pengembangan Budi Daya Ikan Ikan Rawa di Kabupaten Barito Kuala, Kalimantan Selatan. Laporan Penelitian Kerjasama Fakultas Perikanan Unlam dengan Dinas Perikanan dan Kelautan Kalimantan Selatan.

Giri, N., A., Suwirya, K., Pithasari, A.I., and Marzuqi, M. (2007). Pengaruh Kandungan Protein Pakan Terhadap Pertumbuhan Dan Efisiensi Pakan Benih Kakap Merah Lutjanus argentimaculatus. Journal Fish Science, 9(1), 55-62.

Hanief, M.A.R. and Subandiyono, P. (2014). Pengaruh Frekuensi Pemberian Pakan Terhadap Pertumbuhan Dan Kelulushidupan Benih Tawes (Puntius javanicus). Journal of Aquaculture Management and Technology. 3 (4), 67-74.

Hariyadi, B., A. Haryono and Susilo, U. (2005). Evaluasi Efisiensi Pakan Dan Efisiensi Protein Pakan Ikan Karper (Ctenopharyngodon idella) Yang Diberi Pakan Dengan Kadar Karbohidrat Dan Energy Yang Berbeda. Fakultas Biologi. Universitas Soedirman. Purwokerto Banyumas. Jawa Tengah.

Hamzah, M. (2004). Kelulusan Hidupdan Pertumbuhan Juvenil Udang Galah (Macrobachium rosenbergii de Man) pada Berbagai Tingkat Salinitas Media. Tesis. Institut Pertanian Bogor, Bogor.

Iskandar, R. and Elrifadah. (2015). Pertumbuhan Dan Efisiensi Pakan Ikan Nila (Oreochromis niloticus) Yang Diberi Pakan Buatan Berbasis Kiambang. Ziraa'ah, 40 (1): 18-24

Kadarini, T. (2009). Pengaruh Salinitas dan Kalsium terhadap Sintasan dan Pertumbuhan Benih Ikan Balashark (Balanthiocheilus melanopterus). Tesis. Institut Pertanian Bogor, Bogor.

Mahendra. (2015). Kombinasi Kadar Kalium Dan Salinitas Media Pada Performance Juvenil Udang Galah (Macrobrachium rosenbergii de Man). Jurnal Perikanan Tropis. 2(1): $55-71$

Nonthakaew, A., Matan, Na., Aewsiri, T. and Matan Ni. 2015. Caffeine in Foods and Its Antimicrobial Activity. International Food Research Journal 22(1): 9-14

Radona, D., Subagja,J., and Kusmini, I.I. (2017). Kinerja Pertumbuhan Dan Efisiensi Pakan Ikan Tor tambroides Yang Diberi Pakan Komersial Dengan Kandungan Protein Berbeda. Media Akuakultur, 12 (1), 2017, 27-33

Rahman, Z., Mamun, A., Ahmad, I., and Rashid, I. 2019. Influence of Probiotics on the Growth Performance of Sex Reversed Nile Tilapia (Oreochromis niloticus, Linnaeus, 1758) Fry. Journal of Aquaculture Research \& Development. 10(2): 1-7

Suwannasang, A., Suanyuk, N., Issaro, A., Phromkunthong, W., Tantikitti, C., Itami, T and Yoshida, T. (2017). Growth, Immune Responses and Protection of Nile Tilapia Oreochromis niloticus Immunized With Formalin-Killed Streptococcus agalactiae Serotype Ia and III Vaccines. Songklanakarin J. Sci. Technol. 39(4): 430-437 
Taqwa, F.H. (2008). Pengaruh Penambahan Kalium pada Masa Adaptasi Penurunan Salinitas dan Waktu Penggantian Pakan Alami oleh Pakan Buatan terhadap Performa Juvenil Udang vanamei (Litopenaeus vannamei). Tesis. Institut Pertanian Bogor, Bogor.

Taqwa, F.H., D. Djokosetiyanto, and R. Affandi. (2008). Pengaruh Penambahan Kalium pada Masa AdaptasiPenurunan Salinitas terhadap Performa Juvenil Udang vanamei (Litopenaeus vannamei ). J. Aquaculture 3 (3):431-436.

Zaidy, A.B. (2007). Pendayagunaan Kalsium Media Perairan dalam Proses Ganti Kulit dan Konsekuensinyabagi Pertumbuhan Udang Galah (Macrobrachium rosenbergii de Man). Disertasi. Institut Pertanian Bogor, Bogor.

Zonneveld, N., E.A. Huisman, and J.H. Boon. (1991). Prinsip-Prinsip Budidaya Ikan. Translated by PT.Gramedia Pustaka Utama, Jakarta. 